\title{
SEASONAL HABITAT SELECTION BY ELK IN NORTH CENTRAL UTAH
}

\author{
Jeffrey L. Beck ${ }^{1,4}$, Kurt T. Smith ${ }^{1}$, Jerran T. Flinders ${ }^{2}$, and Craig L. Clyde ${ }^{3}$
}

\begin{abstract}
AвstRaCT.-Understanding anthropogenic and environmental factors that influence seasonal habitat selection is critical in establishing conservation objectives for wildlife populations. However, many resource selection studies provide inferences only for single seasons, potentially masking factors essential to populations during other times of the year. Our objective was to model elk (Cervus elaphus) habitat selection for 4 seasons to identify factors influencing selection within and across seasons. Using aerial relocation data, we evaluated seasonal habitat selection for 46 radio-marked, migratory adult female elk in a 6123- $\mathrm{km}^{2}$ landscape in north central Utah, USA, from 1993 to 1997 . We evaluated habitat use and availability within estimated seasonal range boundaries by using binary logistic regression to model habitat selection. Habitat use was measured as a response to predictor variables collected from analysis regions around elk locations. Habitat use was compared to habitat availability by measuring those same variables collected from randomly located analysis regions. Our results showed that roads, topography, and vegetation cover influenced elk habitat selection within and across seasons. Roads did not influence elk habitat selection in spring; rather, elk selected areas with aspen (Populus tremuloides) at higher elevations. In summer, elk selected forage-rich habitats, particularly aspen and mountain brush at higher elevations and on cooler aspects. In fall, elk selected sites with steeper slopes at higher elevations in areas with greater cover of aspen and mountain brush than was available in seasonal range boundaries. In winter, elk selected sagebrush (Artemisia spp.)-meadow cover on steeper slopes at lower elevations away from major roads. The full array of seasonal habitat selection patterns we found provides managers with greater options for setting conservation objectives for elk on a year-round basis.
\end{abstract}

RESUMEN.-El comprender los factores antropogénicos y ambientales que influyen en la selección del hábitat según la estación es fundamental para establecer los objetivos de conservación de las poblaciones de vida silvestre. Muchos estudios relacionados con la selección de recursos sólo proporcionan conclusiones para cada una de las estaciones del año por separado, lo que puede enmascarar factores fundamentales para las poblaciones durante otras épocas del año. Nuestro objetivo fue modelar la selección del hábitat del alce (Cervus elaphus) durante las cuatro estaciones para identificar los factores que influyen en la selección durante y a lo largo de las estaciones. Evaluamos la selección del hábitat, según la estación, de 46 hembras adultas de hábitos migratorios, en un paisaje de $6123 \mathrm{~km}^{2}$ en la zona norte central de Utah, EE. UU., entre los años 1993 y 1997, utilizando la información del traslado obtenida con tomas aéreas. Evaluamos la utilización y disponibilidad del hábitat, dentro de los límites estimados de la zona, según la estación utilizando el método de regresión logística para modelar la selección del hábitat. La utilización del hábitat se midió como respuesta a variables explicativas que se obtuvieron de las regiones que se analizaron en zonas donde se encontraba el alce, en comparación con las regiones que se analizaron al azar para representar la disponibilidad del hábitat. Nuestros resultados demostraron que los caminos, la topografía y la cobertura de vegetación influyeron en la selección del hábitat del alce durante y a lo largo de las estaciones. Los caminos no influyeron en la selección del hábitat del alce durante la primavera, en esa estación, el alce seleccionó áreas en las que había álamo temblón (Populus tremuloides) y matorrales montañosos en terrenos elevados. Durante el verano, el alce seleccionó hábitats con abundancia de alimentos, en particular álamo temblón y matorrales montañosos en terrenos más elevados y en áreas más frescas. Durante el otoño, el alce seleccionó lugares con pendientes más empinadas, en terrenos más elevados, en zonas con mayor cobertura de álamo temblón y matorrales montañosos de la que había en los límites de la zona según la estación. Durante el invierno, el alce seleccionó artemisas (especie Artemisia) que cubrían las praderas en pendientes más empinadas, en terrenos con menor elevación, alejadas de los caminos principales. La variedad de patrones de selección del hábitat según la estación que reportamos, proporciona mejores opciones para establecer los objetivos de conservación del alce durante todo el año.

Understanding anthropogenic and environmental factors that influence seasonal habitat selection is critical in establishing conservation objectives for wildlife populations. To obtain seasonal resources such as forage and cover, large ungulates, including elk (Cervus elaphus), select numerous habitat features across a large spatial scale during a single annual cycle. Habitat selection by elk has been well studied in both forested and nonforested environments throughout the Intermountain West (McCorquodale et al. 1986,

\footnotetext{
${ }^{1}$ Department of Ecosystem Science and Management, University of Wyoming, Laramie WY 82071.

${ }^{2}$ Department of Plant and Wildlife Sciences, Brigham Young University, Provo, UT 84602.

${ }^{3}$ Utah Division of Wildlife Resources, 1115 North Main, Springville, UT 84663.

느-mail: jlbeck@uwyo.edu
} 
Rowland et al. 2000, Beck et al. 2006, Sawyer et al. 2007). Elk tend to avoid anthropogenic features such as roads (Witmer and deCalesta 1985, Rowland et al. 2000) and increase movement and avoidance behaviors in response to off-road recreational activities (Wisdom et al. 2004). Topographic features, including elevation, slope, and aspect, influence elk habitat selection throughout the year (Marcum 1975, Witmer and deCalesta 1985, Edge et al. 1987, Stewart et al. 2002, Sawyer et al. 2007). The gradient of topographic features linked with precipitation and plant phenology provides a diversity of cover and forage availability during different seasonal periods.

Elk populations in mountainous environments move between summer and winter ranges in response to changes in weather conditions, plant phenology, and plant availability (Sweeney and Steinhoff 1976). Spring and fall habitats are used as stopover locations for migratory ungulates. These habitats provide rest, cover, and forage during the transition between summer and winter ranges (Sawyer and Kauffman 2011). Because of the high degree of variability in migrations among separate elk populations (Skovlin et al. 2002), the spatial scale necessary for individuals to meet their seasonal energetic requirements may be largely associated with the juxtaposition of seasonal habitats. Identifying habitat features that may simultaneously influence selection and seasonal habitat use at a yearly temporal scale provides a more holistic approach to elk management and guides landuse practices and conservation efforts.

Although several studies have evaluated elk habitat use during 1 or 2 seasonal periods (e.g., Marcum 1975, Grover and Thompson 1986, Edge et al. 1987, Boyce et al. 2003, Beck et al. 2006, Sawyer et al. 2007), research evaluating seasonal requirements on a yearround basis is scarce (but see Witmer and deCalesta 1983, Unsworth et al. 1998). To date, elk habitat selection studies have not incorporated the variability and spatial distribution of key habitat features that influence selection across seasons, thereby potentially neglecting the suite of habitat characteristics that are selected by elk on a year-round basis. The purpose of our study was to evaluate seasonal habitat selection for migratory elk within a large landscape in north central Utah that encompassed all seasonal habitats (Fig. 1). Our objective was to model elk habitat selection during spring, summer, fall, and winter to identify factors influencing selection by this population within and across seasons. We predicted elk seasonal habitat selection to reflect road influences, variation in cover, and topographic attributes that maximize the trade-off between forage acquisition and security cover.

\section{Methods \\ Study Area}

Our study area encompassed $6123 \mathrm{~km}^{2}\left(39^{\circ}\right.$ $59^{\prime} \mathrm{N}, 110^{\circ} 47^{\prime} \mathrm{W}$ ) administered by the $\mathrm{Bu}-$ reau of Land Management $\left(992 \mathrm{~km}^{2}, 16.2 \%\right)$, United States Forest Service $\left(2447 \mathrm{~km}^{2}, 40.0 \%\right)$, Utah Division of Wildlife Resources $\left(355 \mathrm{~km}^{2}\right.$, $5.8 \%)$, private ownership $\left(1645 \mathrm{~km}^{2}, 26.9 \%\right)$, and other ownership $\left(684 \mathrm{~km}^{2}, 11.1 \%\right)$ in Carbon, Duchesne, Utah, and Wasatch counties, Utah, USA (Fig. 1), at elevations ranging from 1400 to $3353 \mathrm{~m}$. Ninety-five percent fixedkernel ranges (Horne and Garton 2009) computed by season were $4059 \mathrm{~km}^{2}$ for spring, $1659 \mathrm{~km}^{2}$ for summer, $3541 \mathrm{~km}^{2}$ for fall, and $5616 \mathrm{~km}^{2}$ for winter (Fig. 1). There were 2 U.S. Natural Resources Conservation Service SNOTEL sites in the summer range portion of our study area. The 19-year (1979-1997) average annual precipitation for the White River 1 SNOTEL site $\left(39^{\circ} 58^{\prime} \mathrm{N}, 110^{\circ} 59^{\prime} \mathrm{W} ; 2634 \mathrm{~m}\right)$ was $64.4 \mathrm{~cm}$ and $85.9 \mathrm{~cm}$ at the Strawberry Divide SNOTEL site $\left(40^{\circ} 11^{\prime} \mathrm{N}, 111^{\circ} 13^{\prime} \mathrm{W}\right.$; $2476 \mathrm{~m}$; NRCS 2011). Most of the moisture precipitated as snow during late fall, winter, and early spring (U.S. Soil Conservation Service 1993). Dominant vegetation communities on the summer range included aspen (Populus tremuloides); conifer species including Douglas-fir (Pseudotsuga menziesii) and subalpine fir (Abies lasiocarpa); sagebrush-grassland consisting of mountain big sagebrush (Artemisia tridentata vaseyana), silver sagebrush (Artemisia cana), and yellow rabbitbrush (Chrysothamnus viscidiflorus); a mountain brush zone including bigtooth maple (Acer grandidentatum), Gambel oak (Quercus gambelii), and red elderberry (Sambucus racemosa); and riparian areas with willows (Salix spp.). Winter range vegetation included mountain brush consisting of Gambel oak and bigtooth maple; conifers including Utah Juniper (Juniperus osteosperma), two-needle pinyon pine (Pinus edulis), and white fir (Abies concolor); and 


\section{Elk Seasonal Ranges North-Central Utah (1993-1997)}

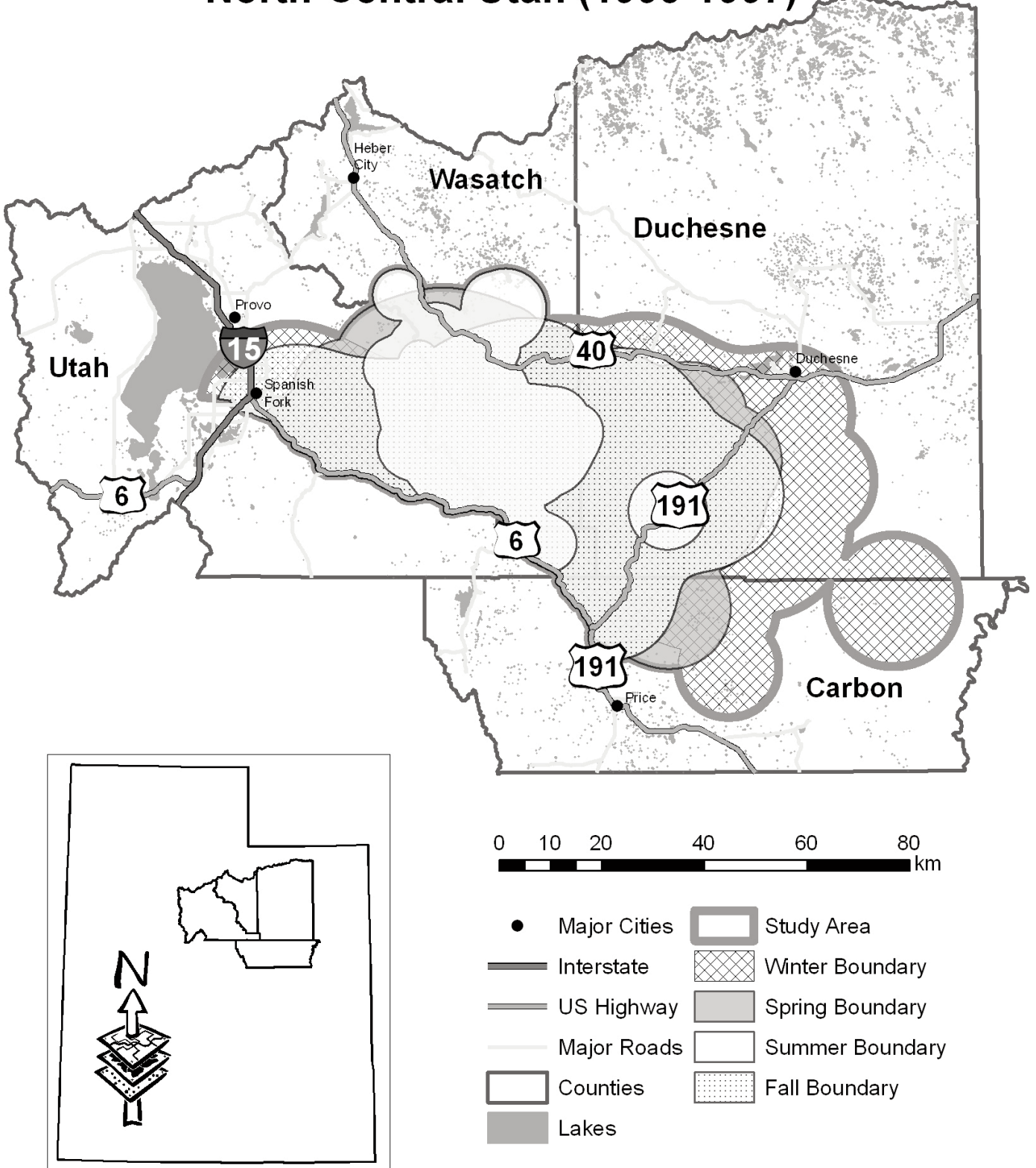

Fig. 1. Map of the study area illustrating elk seasonal ranges in north central Utah, USA, 1993-1997. Ninety-five percent fixed-kernel ranges computed by season were $4059 \mathrm{~km}^{2}$ for spring, $1659 \mathrm{~km}^{2}$ for summer, $3541 \mathrm{~km}^{2}$ for fall, and $5616 \mathrm{~km}^{2}$ for winter.

Wyoming big sagebrush (Artemisia tridentata wyomingensis). Spring and fall ranges were composed of a mixture of winter and summer plant communities. Grazing of domestic sheep and cattle was common on public and private lands on spring, summer, and fall ranges. Recreational uses in our study area included camping, fishing, hunting, off-road vehicle touring, and snowmobiling, the last of which primarily occurred on elk summer range. 


\section{Capture and Relocation}

We used helicopter net gunning (Helicopter Wildlife Management, Salt Lake City, UT) to capture 40 adult female elk on 22 and 23 July 1993 on lands administered by the USDA-Uinta National Forest. Thirty elk were captured within the $100-\mathrm{km}^{2}$ Willow Creek drainage and 10 elk along Strawberry Ridge, immediately adjacent to the west of Willow Creek. Each elk was equipped with a very high frequency (VHF) radio-collar (Lotek, Newmarket, Ontario, Canada). Seven of the 40 cows were harvested during the fall 1993 hunting season; 6 of these collars were reaffixed to adult female elk in the Willow Creek drainage on 11 July 1994. We located collared elk from the air with a Cessna 185 aircraft equipped with telemetry receivers at approximately 1month intervals to facilitate systematic sampling (Scheaffer et al. 1996). Latitude and longitude of elk locations were recorded with the Loran-C navigation system (accuracy $174.3 \mathrm{~m}$ $\pm 99.5 \mathrm{~m}$; Leptich et al. 1994) for 51 flights from 23 July 1993 to 23 June 1997 during morning hours and across spring, summer, fall, and winter. Data from 8 flights were omitted from our analysis due to inaccuracy.

\section{Habitat Measurements}

We identified habitat variables that were predictive of elk habitat selection in other studies, including vegetation characteristics, topography, and anthropogenic features (Witmer and deCalesta 1985, Edge et al. 1987, Rowland et al. 2000, Stewart et al. 2002, Beck et al. 2006, Sawyer et al. 2007). We obtained a $30 \times 30-\mathrm{m}$ resolution Landsat 5 Thematic Mapper image from the U.S. Geological Survey to classify cover in the study area as aspen, conifer, mountain brush, sagebrushmeadow, and perennial water. We grouped sagebrush and herbaceous meadows into a single cover type because we often observed elk foraging in these open communities near woody cover and because sagebrush often grew in meadows. We used ERDAS IMAGINE $9.3\left(\right.$ ERDAS $^{\circledR}$, Inc., Atlanta, GA) and ArcMap 9.3 (Environmental Systems Research Institute, Redlands, CA) to cluster pixels into spectrally similar cover features. Then we converted these pixels to a polygon database and dissolved the classified polygons into the 4 vegetation cover classes and perennial water sources. Cover classification accuracy was assessed by comparing 597 elk locations with habitat classifications recorded during flights. Classifications were considered correct if aerial habitat classifications were recognized within the region of error for projected elk locations. We evaluated agreement between aerial classifications and map predictions with Cohen's Kappa Coefficient (Cohen 1960; Cohen's $\mathrm{k}=0.896)$. We calculated the proportion of each cover class within the circular analysis region around each used and randomly available location and also calculated the distance from each used and available location to the nearest perennial water source by using the Nearest Neighbor extension for ArcMap 9.3.

The Spatial Analyst extension for ArcMap was used to calculate aspect and mean elevation and slope within each circular analysis region from a $30 \times 30$-m digital elevation model (USGS 1999). The dominant aspect in the grid cells forming each circular analysis region were classified as warm $\left(136-314^{\circ}\right)$ or cool $\left(315-135^{\circ}\right)$. We used the Vector Ruggedness Measure (VRM), which is the difference in radians between the cells formed from a digital elevation model grid cell and its immediately surrounding cells, to measure average terrain ruggedness within each circular analysis region. The VRM ranges from 0 (no terrain variation) to 1 (complete terrain variation), with typical values for natural terrain ranging between 0 and approximately 0.4 (Sappington et al. 2007). VRM values were calculated using a $3 \times 3$ cell format (Sappington et al. 2007) and then rescaled by multiplying the original values by 1000 for interpretation. We obtained a road dataset (Utah Automated Geographic Reference Center) and classified roads as either minor (low-maintenance gravel or 2-track) or major (well-maintained and paved surfaces). The Nearest Neighbor extension was used to measure the distance from the center of each analysis region to the nearest minor and major road.

\section{Study Design}

We employed a use-availability design to evaluate elk seasonal habitat selection (Boyce et al. 2002, Manly et al. 2002, Johnson et al. 2006), where we identified resource use as locations obtained from fixed-wing aircraft of radio-collared elk during 1993-1997. Locations were pooled across individual elk to represent a population-level habitat selection 
response (a Type 1 Design; Manly et al. 2002, Thomas and Taylor 2006). It is important to consider annual variation in habitat selection models if resource use varies between years (Schooley 1994). However, we observed no indication of behavioral differences in elk within seasons across the 4 years of our study. Therefore, to increase sample size and account for seasonal selection patterns that may be observed in the same areas across years, we included elk locations from all 4 years in the same seasonal models (Carpenter et al. 2010). Furthermore, we focused our analysis on habitat components within a home range (i.e., Johnson's [1980] third-selection order), whereby we constrained habitat availability within seasonal home-range boundaries. When multiple elk were located within a 300-m radius during a single flight, we randomly removed locations until no locations were within $300 \mathrm{~m}$ of one another to ensure that locations were selected independently. We based our removal distance on field observation of elk herd behavior, which resulted in $<1 \%$ of locations removed. Numbers of locations per elk in a given season were equalized to avoid overrepresentation of the selection response of individuals. We randomly selected 1000 locations within each seasonal boundary, excluding locations in bodies of water, to represent available habitat.

We defined seasons by changes in elk behavior, summarized by distance moved from locations collected during previous fixed-wing aircraft flights, as winter, 9 December-7 March; spring, 8 March-3 June; summer, 4 June-28 September; and fall, 29 September-8 December (Fig. 1). We calculated $100 \%$ fixed-kernel home ranges for each independent flight and used smoothing factors ( $\mathrm{H}$ values) for these home ranges based on the elk locations from each flight, with likelihood cross-validation (Horne and Garton 2006, 2009). To define seasonal boundaries, we generated a $95 \%$ fixedkernel area around individual home ranges from each flight that occurred within a season. Our seasonal home-range boundaries were truncated along U.S. Highway 6 on the south and near Spanish Fork on the west, because elk locations did not occur past these landmarks and because our observations indicated they likely formed barriers to movement (Fig. 1). For each season, we estimated daily movement of elk by dividing the average distance moved between locations by the number of days between subsequent flights. We used estimated daily movements to create circular analysis regions around used and available locations. These regions accounted for the area that was hypothetically available to elk on a daily basis, but also exceeded flight location error.

\section{Data Analysis}

We used 95\% Bailey's simultaneous confidence intervals (Bailey 1980) in Resource Selection Version 1.0 (Leban 1999) to assess elk preference and avoidance of vegetation cover types for each season. Independent sample $t$ tests were used to assess differences in continuous explanatory variables between used and available locations in each season. A Fisher's exact test was used to assess the proportion of cool and warm aspects between elk and available locations.

We employed binary logistic regression with used and available locations for model selection. For each season, we determined the probability of use within seasonal range boundaries where used and available locations were the dependent variables and a suite of habitat characteristics formed our set of predictor variables for each season (Johnson et al. 2006). We conducted statistical analyses with Statistical Analysis Software (SAS) version 9.2 (SAS Institute, Inc. 2009). We removed nonpredictive variables to prevent model overfitting (Burnham and Anderson 2002). We tested each predictive variable individually and removed it if the $95 \%$ confidence interval (CI) for the odds ratio overlapped 1.0 (Arnold 2010). We computed a Pearson's correlation matrix to test for multicollinearity among the variables and eliminated one of each correlated variable when correlation coefficients $(r)$ were $\geq|0.6|$ by retaining the variable with the lowest log-likelihood value (Doherty et al. 2010). We further tested multicollinearity with the collinearity tolerance option in PROC REG (SAS Institute, Inc. 2009). Variables with low tolerance $(\mathrm{t} \leq 0.4)$ were removed from further analysis. Finally, we did not allow variables to compete in the same model when the signs of coefficients switched in the presence of another variable. Instability in the signs of coefficients can be a sign of moderate correlation and can lead to inflated standard errors (Doherty 2008). We evaluated all possible combinations of remaining variables in logistic regression models (Carpenter et al. 2010). 
We used 2nd-order Akaike's information criterion corrected for small sample sizes $\left(\mathrm{AIC}_{c}\right.$; Burnham and Anderson 2002) to rank all candidate models for each season by degrees of support. We computed cumulative Akaike weights $\left(w_{i}\right)$ for all candidate models to provide weights of evidence in support of each seasonal model being the most parsimonious compared to the other models under consideration (Burnham and Anderson 2002). We followed the convention that models with weights of evidence $\left(w_{i}\right)$ within $90 \%$ of the best model were competitive (Burnham and Anderson 2002, Arnold 2010). When a single top model was not evident based on the weight of evidence $\left(w_{i}\right)$, we performed a model-averaging procedure to calculate mean coefficients, standard errors, confidence intervals, and odds ratios for each variable in the model-averaged set. We quantified the relative importance (RI) for each variable by summing the Akaike weights for each variable across all the models it occurred in (Burnham and Anderson 2002).

Lastly, we performed a 5-fold cross-validation procedure to evaluate goodness-of-fit for our best elk habitat selection model for each season (Boyce et al. 2002, Beck et al. 2006). We followed the approach of Sawyer et al. (2007) to map model predictions for each season across $30 \times 30$-m pixels in our study area to provide a depiction of the spatial array of selection probabilities. We report all estimates as means with one standard error (SE), and we set statistical significance at $\alpha=0.05$.

\section{RESUlTS}

From July 1993 to June 1997, we obtained 1063 elk locations from 43 aerial flights (spring, 8 flights; summer, 15 flights; fall, 9 flights; winter, 11 flights). Of these locations, we used 150 from 25 elk in spring, 240 from 30 elk in summer, 145 from 29 elk in fall, and 168 from 28 elk in winter. Circular analysis regions located based on daily movement radii around elk-used and randomly available locations were $0.554 \mathrm{~km}^{2}$ in spring, $0.126 \mathrm{~km}^{2}$ in summer, $0.528 \mathrm{~km}^{2}$ in fall, and $0.166 \mathrm{~km}^{2}$ in winter.

\section{Spring Habitat Selection}

In spring, elk preferred aspen $(P<0.001)$, avoided sagebrush-meadow $(P<0.05)$, and used conifer and mountain brush in proportion to their availability (Fig. 2). Distance to minor roads, major roads, and water, as well as percent conifer, percent slope, aspect, and topographic ruggedness (VRM), did not differ among elk-used and available locations (Appendix 1). In spring, elk selected higher elevations (used $=2471 \mathrm{~m}, \mathrm{SE} 19$; available $=$ $\left.2352 \mathrm{~m}, \mathrm{SE} 8 ; t_{1148}=5.25, P<0.001\right)$ in areas with higher aspen cover (used $=25.0 \%, \mathrm{SE}$ $1.9 ;$ available $=17.1 \%$, SE $0.6 ; t_{1148}=4.63, P$ $<0.001)$ and lower sagebrush-meadow cover (used $=42.8 \%$, SE 2.5; available $=52.3 \%$, SE $\left.1.1 ; t_{1148}=3.14, P=0.002\right)$ compared to available locations (Appendix 1).

The logistic regression model that best explained elk habitat selection in spring included elevation and percent aspen (Appendix 2 ). The global model was competitive with the top model $\left(\Delta \mathrm{AIC}_{c}=1.35\right)$ and included percent aspen, percent mountain brush, and elevation. Model averaging indicated that the 95\% confidence interval for the odds ratio estimate of mountain brush overlapped 1 (Appendix 3); therefore, we considered mountain brush to be an uninformative predictor and limited our top spring model to include aspen and elevation. Relative importance weights for variables in the top models ranged from 0.99 to 1.0 ; relative importance for mountain brush was 0.34 . For every $10 \%$ increase in aspen cover, the likelihood of elk use increased by approximately $4.3 \%$ (Fig. 3). With an increase of $100 \mathrm{~m}$ elevation, the likelihood of elk use increased by approximately 3.5\% (Fig. 3). Our cross-validation analysis indicated that our best model was a strong, positive predictor of elk habitat use in spring $\left(r_{\mathrm{S}}=\right.$ $0.87, P=0.001, n=10)$.

\section{Summer Habitat Selection}

During summer, aspen $(P<0.001)$ and mountain brush $(P<0.001)$ were preferred, sagebrush-meadow $(P<0.001)$ was avoided, and conifer was used in proportion to its availability (Fig. 2). Distance to major roads and water, as well as percent conifer, percent slope, and topographic ruggedness (VRM), did not differ among elk-used and available locations (Appendix 1). In summer, elk selected habitats at higher elevations (used $=2610 \mathrm{~m}$, $\mathrm{SE} \mathrm{10}$; available $=2482 \mathrm{~m}, \mathrm{SE} 7 ; t_{1238}=8.27$, $P<0.001$ ); closer to minor roads (used $=0.5$ $\mathrm{km}$, SE 0.03; available $=0.6 \mathrm{~km}$, SE 0.02 ; 

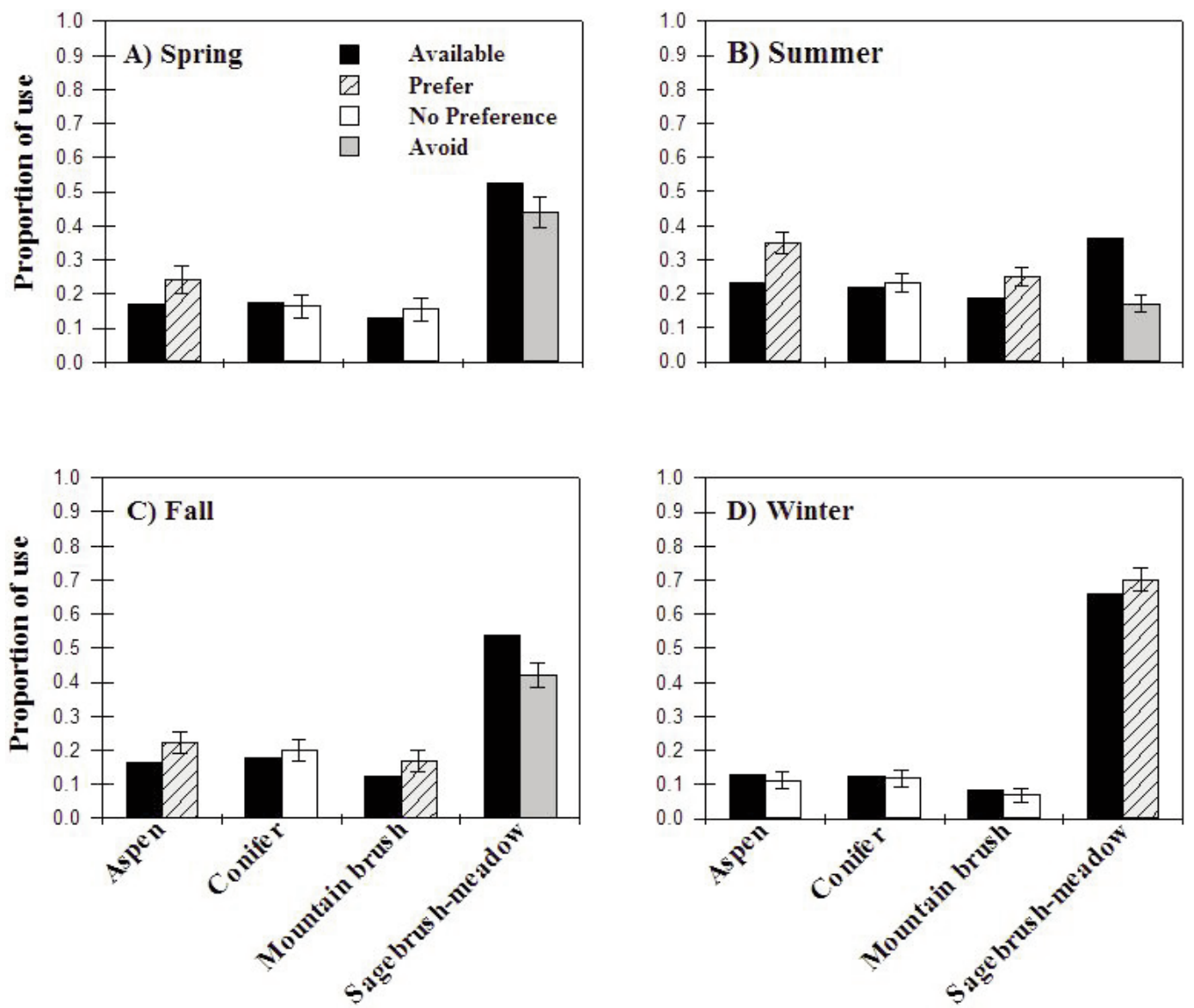

Fig. 2. Proportions of aspen, conifer, mountain brush, and sagebrush-meadow cover types at elk-used and available locations during spring (A), summer (B), fall (C), and winter (D) in north central Utah, USA, 1993-1997. Error bars depict Bailey's $95 \%$ confidence intervals estimating preference, use proportional to availability, and avoidance of different habitat types by season.

$\left.t_{1238}=3.04, P=0.002\right) ;$ with higher cover of aspen (used $=34.7 \%$, SE 1.6; available $=$ $22.5 \%$, SE $\left.0.7 ; t_{1238}=7.51, P<0.001\right)$ and mountain brush (used $=25.1 \%$, SE 1.4; available $=18.3 \%$, SE $\left.0.6 ; t_{1238}=4.56, P<0.001\right)$ and lower cover of sagebrush-meadow (used $=17.0 \%$, SE 1.6; available $=35.2 \%$, SE 1.1; $\left.t_{1238}=7.58, P<0.001\right)$; and on cooler aspects $(P=0.008$; Appendix 1$)$.

Our top 5 logistic regression models were competitive in explaining elk summer habitat selection $\left(\Delta \mathrm{AIC}_{c} \leq 3.94\right.$; Appendix 2$)$. Potential explanatory variables included minor roads, aspect, elevation, and percent cover of aspen, mountain brush, and sagebrush-meadow (Appendix 3). Model-averaged 95\% confidence intervals around the odds ratios for minor roads and sagebrush-meadow overlapped 1 (Appendix 3); therefore, we considered our most competitive summer model to include aspect, elevation, and percent cover of aspen and mountain brush. Weights for the most explanatory variables supporting our model were 0.88 for aspect, 1.00 for aspen, 0.99 for mountain brush, and 1.0 for elevation. For every $10 \%$ increase in aspen and mountain brush cover, the likelihood of elk use increased by approximately $10.1 \%$ and $8.7 \%$, respectively (Fig. 3). With an increase of $100 \mathrm{~m}$ elevation, the likelihood of elk use increased by approximately $11.0 \%$ (Fig. 3). Cross-validation indicated that the best model was a very strong, positive predictor of elk habitat use in summer $\left(r_{\mathrm{S}}=0.97, P<0.001, n=10\right)$. 

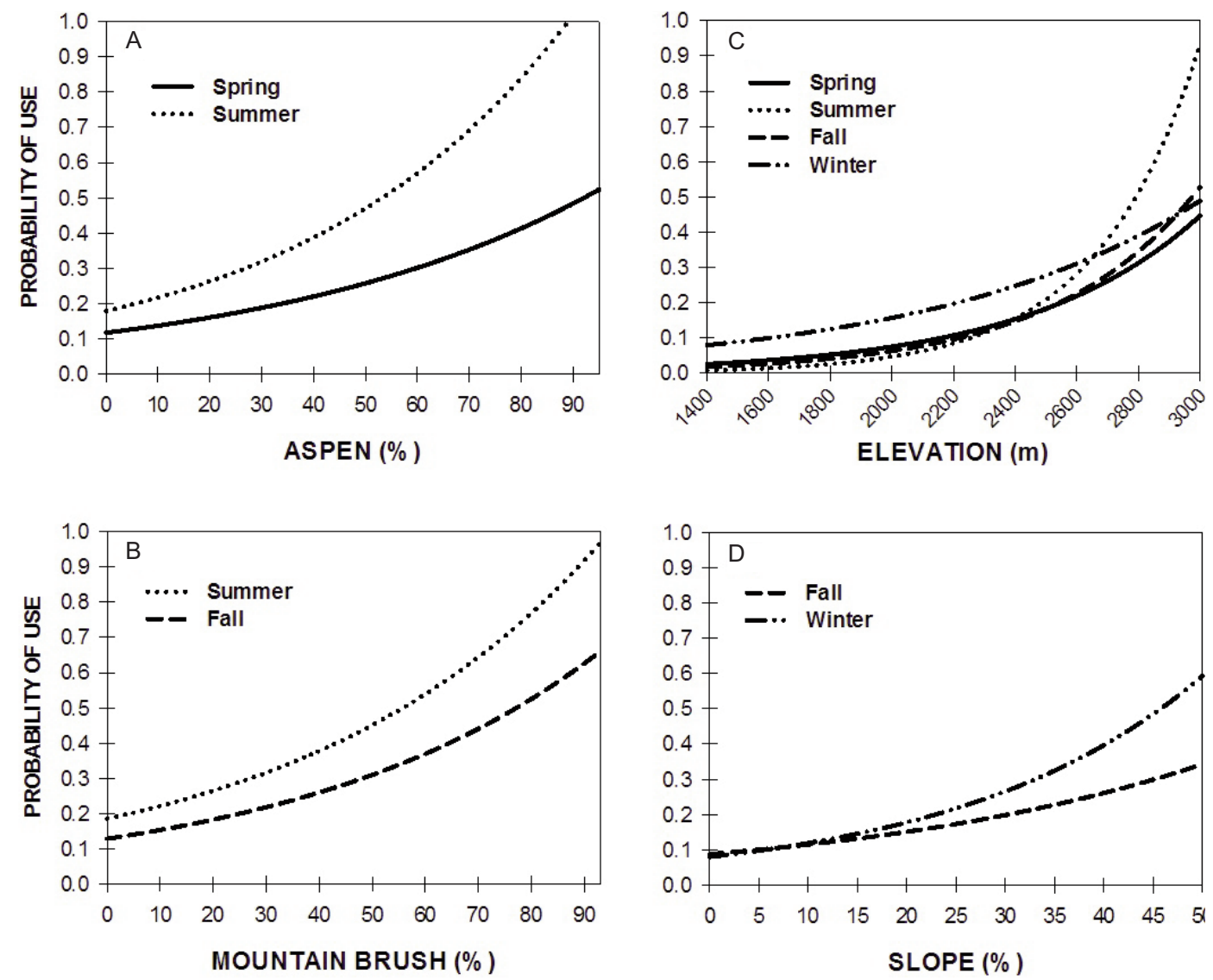

Fig. 3. Probability of elk use of spring, summer, fall, and winter habitats as a function of percent aspen (A), percent mountain brush (B), elevation (C), and slope (D) in north central, Utah, USA, 1993-1997. Probability graphs were derived from final models for each season. Variables of interest were free to vary, whereas other variables in each model were held at their mean values. Upper limits of variables were truncated based on the maximum values within circular analysis regions recorded for use locations within respective seasons.

\section{Fall Habitat Selection}

In fall, aspen $(P<0.05)$ and mountain brush $(P<0.05)$ were preferred, sagebrushmeadow was avoided $(P<0.001)$, and conifer was used equal to availability (Fig. 2). Aspect and distance to water were the only explanatory variables that did not differ among elkused and available locations (Appendix 1). In fall, elk selected habitats farther from minor (used $=0.9 \mathrm{~km}, \mathrm{SE} 0.07$; available $=0.7 \mathrm{~km}$, SE $\left.0.02 ; t_{1143}=2.86, P=0.004\right)$ and major (used $=5.4 \mathrm{~km}, \mathrm{SE} 0.30$, available $=4.5 \mathrm{~km}$, SE $\left.0.12, t_{1143}=2.67, P=0.008\right)$ roads, as well as areas with greater aspen (used = $22.2 \%$, SE 1.7 ; available $=16.5 \%$, SE 0.6 ; $t_{1143}=3.19, P=0.001$ ), conifer (used $=$ $20.8 \%$, SE 1.4 ; available $=17.5 \%$, SE 0.6 ; $\left.t_{1143}=2.02, P=0.044\right)$, and mountain brush (used $=16.8 \%$, SE 1.4; available $=12.2 \%, \mathrm{SE}$ $\left.0.5 ; t_{1143}=3.32, P<0.001\right)$. Habitat selected by elk in fall also included less sagebrushmeadow (used $=40.2 \%$, SE 2.5; available $=$ $53.6 \%$, SE $1.1 ; t_{1143}=4.38, P<0.001$ ), steeper slopes (used $=25.0 \%$, SE 0.9; available $=21.6 \%$, SE $0.4 ; t_{1143}=3.38, P<$ 0.001 ), higher elevation (used $=2477 \mathrm{~m}, \mathrm{SE}$ 20 ; available $=2357 \mathrm{~m}$, SE $8 ; t_{1143}=5.27, P$ $<0.001$ ), and higher VRM (used $=8.2, \mathrm{SE}$ 0.5 ; available $=6.2$, SE $0.2 ; t_{1143}=4.49, P<$ $0.001)$ compared to available locations.

The logistic regression model best explaining fall elk habitat selection included percent mountain brush, slope, and elevation (Appendix 2). The global model was competitive with 
the top model $\left(\Delta \mathrm{AIC}_{c}=0.84\right)$ and included elevation, slope, and percent cover of aspen and mountain brush. Model-averaged 95\% confidence intervals around the odds ratio for aspen cover overlapped 1 (Appendix 3); therefore, we considered our most competitive fall model to include elevation, slope, and percent mountain brush. Weights for the most explanatory variables supporting our model were 0.98 for mountain brush, 0.99 for slope, and 0.99 for elevation. For every $10 \%$ increase in mountain brush cover, the likelihood of elk use increased by approximately 5.9\% (Fig. 3). With an increase of $100 \mathrm{~m}$ elevation, the likelihood of elk use increased by approximately $4.7 \%$ (Fig. 3). The likelihood of elk use increased by approximately 5\% with every $10 \%$ increase in slope (Fig. 3). Cross-validation indicated that our best model was a very strong, positive predictor of elk habitat use during fall $\left(r_{\mathrm{s}}=0.96, P<0.001, n=10\right)$.

\section{Winter Habitat Selection}

During winter, sagebrush-meadow was preferred $(P<0.05)$, whereas aspen, conifer, and mountain brush were used in proportion to their availability (Fig. 2). Aspect and percent cover of aspen, conifer, mountain brush, and sagebrush-meadow did not differ among elkused and available locations (Appendix 1). In winter, elk selected habitats farther from minor $($ used $=0.9 \mathrm{~km}, \mathrm{SE} 0.06$; available $=0.6$ $\left.\mathrm{km}, \mathrm{SE} 0.02 ; t_{1166}=4.45, P<0.001\right)$ and major (used $=6.5 \mathrm{~km}, \mathrm{SE} 0.3$; available $=4.9$ $\mathrm{km}$, SE $\left.0.1 ; t_{1166}=4.81, P<0.001\right)$ roads. Elk selected habitat farther from water (used = $1.6 \mathrm{~km}$, SE 0.1; available $=1.4 \mathrm{~km}$, SE 0.03 ; $\left.t_{1166}=2.03, P=0.042\right)$, on steeper slopes (used $=26.8 \%$, SE 1.1; available $=18.9 \%, \mathrm{SE}$ $\left.0.4 ; t_{1166}=6.82, P<0.001\right)$, at higher elevations (used $=2348 \mathrm{~m}$, SE 21; available $=$ $\left.2269 \mathrm{~m}, \mathrm{SE} 9 ; t_{1166}=3.42, P<0.001\right)$, and at sites with greater VRM (used $=8.4$, SE 0.5; available $=5.6$, SE $0.2 ; t_{1166}=5.53, P<$ $0.001)$ than at random sites.

We considered our top 2 logistic regression models to be competitive in explaining elk habitat selection in winter $\left(\Delta \mathrm{AIC}_{c} \leq 4.35\right.$; Appendix 2). Potential explanatory variables included distance to minor roads, percent sagebrush-meadow, percent slope, and elevation (Appendix 3). Model-averaged 95\% confidence intervals for the odds ratios for all explanatory variables did not include 1 ; therefore, we retained all variables in our top model. Weights for the most explanatory variables were 0.89 for minor roads, 0.99 for percent sagebrushmeadow, 0.99 for percent slope, and 0.99 for elevation. For every $10 \%$ increase in slope, the likelihood of elk use increased by approximately $10.8 \%$ (Fig. 3). With an increase of 100 $\mathrm{m}$ elevation, the likelihood of elk use increased by approximately 5.8\% (Fig. 3). Crossvalidation indicated that the best model was a strong, positive predictor of elk habitat use in winter $\left(r_{\mathrm{s}}=0.83, P=0.003, n=10\right)$.

\section{Discussion}

Studies aimed at identifying factors that influence habitat selection during a single season may not incorporate the temporal scale necessary to prioritize habitats on a yearround basis. Our study design allowed us to evaluate the relative effect of several habitat variables that influence elk habitat selection across seasons. Our results demonstrated that female elk in north central Utah showed strong selection for a suite of vegetation cover types and topographical characteristics during each season. In spring, elk disproportionately used habitats with greater aspen cover, less sagebrush-meadow, and greater elevation compared to available habitats. The variables that best predicted elk use in spring were aspen and elevation. In summer, elk selected locations in cooler aspects with greater cover of aspen and mountain brush, as well as lower sagebrush-meadow cover at higher elevations closer to minor roads. Distance to minor roads, however, was not predictive of selection, but was probably indicative of elk using flatter terrain near areas where minor roads tended to be located, as well as less human activity on these roads in summer. Fall habitats consisted of greater slope and elevation in areas with greater aspen, conifer, and mountain brush cover. During fall, elk used areas with less sagebrush-meadow cover farther from roads. During winter, elk selected locations in lower-elevation sagebrush habitats on steeper slopes far from major roads.

Our results support the notion that animals select habitats to maximize fitness on a seasonal basis. Vegetation provides food resources and structural cover for elk on a year-long basis. We found strong selection for aspen, mountain brush, and sagebrush-meadow cover. 
We found no support for selection of coniferous habitats in any season. However, locations of elk were in areas with equal availability of conifer compared to available points. The importance of conifer stands as security cover to elk is well known (Irwin and Peek 1983, Rowland et al. 1984, Skovlin et al. 2002). Use of conifer habitat by elk in our study in proportion to its availability in all seasons may reflect the relatively homogenous distribution of this cover type. Stands of mixed aspen and conifer provide areas of security cover during periods of inactivity between foraging bouts (Irwin and Peek 1983, Anderson et al. 2005) and when human activity is high (Millspaugh et al. 2000). Cover requirements have been studied extensively (Thomas et al. 1979, Edge et al. 1990) and vary with seasonal temperature and precipitation regimes. We suspect that selection of conifer stands implies the presence of a mixture of vegetation and complex topography that creates suitable security cover, especially during fall (Thomas et al. 1979, Skovlin et al. 2002).

Aspen typically occurs at intermediate elevation in areas where high snowpack provides moisture for growth of shrubs, grasses, and succulent forbs (Mueggler 1988) that are typical of elk diets during spring, summer, fall, and winter (Kufeld 1973, DeByle 1985, Beck et al. 1996, Beck and Peek 2005a). Aspen has considerable value as forage for elk during all seasons (Kufeld 1973, DeByle 1985). The adjacency of forage to the dense canopy cover of mature timber stands creates edge habitats characteristically used by elk (Witmer and deCalesta 1983, Grover and Thompson 1986, McCorquodale 2003). The selection of mountain brush during summer and fall may have been associated with a shift in forage availability. We found a preference for aspen cover in fall, but aspen was not considered an influential variable in the fall model. Two of the most common mountain brush species in our study area were red elderberry and Gambel oak. Both species occur in a variety of subalpine vegetation zones in Utah (Conrad and McDonough 1972) and are highly palatable to elk during late summer, fall, and winter when other forage is less available (Conrad and McDonough 1972, Mower and Smith 1989, Beck et al. 1996). Elk shifted to sagebrush-dominated landscapes at the onset of winter when habitat availability was restricted to lower elevations. This shift is common for many elk populations (Irwin and Peek 1983, Unsworth et al. 1998, Mao et al. 2005).

We found that topographic features influence habitat selection during all seasons. The elevational range ( 1400-3350 m) in our study area provided elk with a variety of topographic features to choose from in their seasonal habitat selection. During winter, elk typically select areas of lower elevation where navigation through snow is more manageable and forage is more available. Steeper windswept slopes in areas of deep snow allow for greater access to available food sources. In spring, elk occupied areas of mid-elevation, likely following a nutritional gradient of plant phenology associated with snow retreat (Sawyer and Kauffman 2011). Crude protein declines in plants over time, suggesting that forage quality for elk is at an optimum during periods of new growth (Beck and Peek 2005b). In our study, the average distance elk moved between summer and winter ranges was $33.1 \mathrm{~km}$ (range 17.5-57.8 $\mathrm{km}, n=28)$. In summer, elk selected cooler aspects at higher elevations in areas containing aspen and mountain brush, suggesting a movement response to areas of higher forage quality and also avoidance of harassment from tabanid (blood-sucking) flies (Beck et al. 1996). During summer, north-facing slopes at higher elevations in more mesic environments provide higher-quality forage while simultaneously affording thermal escape from elevated temperatures (Witmer and deCalesta 1983). Edge et al. (1987) found a similar preference for higher elevations as summer progressed in western Montana. Although elk used moderate slopes $(18.7 \pm 0.6 \%)$, we found no evidence for selection of slope during summer. In fall, elk occupied areas with complex topography of moderate elevation and steeper slopes, offering greater security and escape cover from hunters. By comparison, Edge and Marcum (1991) found that probability of elk use was greatest when topographic relief afforded visual separation from roads, and Webb et al. (2011) reported that a mix of vegetative cover and topographical features may minimize disturbance to elk by reducing visual detection from nearby human disturbances.

Elk in our study area used locations farther from roads only in fall and winter, and selection away from minor roads was documented only in winter. Other factors besides human 
activity, including topography, cover, and climatic conditions, may have also influenced selection of habitat away from roads in these seasons; however, the tendency of elk to avoid areas near roads has been well documented (Lyon 1983, Witmer and deCalesta 1985, Rowland et al. 2000, Wisdom et al. 2004). Roads were generally located in areas of less complex topography relative to areas of higher elevation used by elk in spring and summer. In addition, many minor roads in our study area were inaccessible in spring due to snow drifts, fallen trees, and mud, thereby reducing their use by motorists and concomitantly reducing avoidance by elk. Although we have no supportive data, we found that vehicular traffic in summer was primarily limited to activities associated with livestock management but greatly increased in fall during hunting seasons. We assume that an increase in vehicular traffic during fall hunting seasons, as well as increased recreational activities in winter, caused elk to utilize areas farther from roads.

\section{Recommendations}

Roads, topography (aspect, slope, elevation), and cover types (aspen, mountain brush, and sagebrush-meadow) were selected by elk within and across seasons. Our results indicate that elk spring and summer habitat management should focus efforts on conserving aspen and mountain brush communities at higher elevations. Fall habitat management should consider actions that maintain a diversity of mountain brush and aspen cover in areas with complex topography and few roads. Managers should target lower-elevation sagebrush habitats on steeper slopes far from roads for winter habitat security. The variation in seasonal habitats, coupled with the relative isolation of habitats from each other, suggests that evaluation of single-season resource selection for elk is insufficient to explain the variation in factors that influence selection on a larger temporal scale. The full array of seasonal habitat selection patterns we found provides managers with greater options for setting conservation objectives for elk on a year-round basis.

\section{ACKNOWLEDGMENTS}

We greatly appreciate insights from E.O. Garton, M.J. Kauffman, and H. Sawyer relative to our approaches to habitat selection modeling. D.R. Nelson from the Uinta National Forest provided logistical support. J.P. Ongstad assisted in the early stages of data analysis. The Rocky Mountain Elk Foundation, Uinta National Forest, and Utah Division of Wildlife provided funding.

\section{Literature Cited}

Anderson, D.P., M.G. Turner, J.D. Forester, J. Zhu, M.S. Boyce, H. Beyer, and L. STOWELl. 2005. Scale-dependent summer resource selection by reintroduced elk in Wisconsin, USA. Journal of Wildlife Management 69:298-310.

ARNOLD, T.W. 2010. Uninformative parameters and model selection using Akaike's information criterion. Journal of Wildlife Management 74:1175-1178.

BAILEY, B.J.R. 1980. Large sample simultaneous confidence intervals for the multinomial probabilities based on transformation of the cell frequencies. Technometrics 22:583-589.

Beck, J.L., J.T. Flinders, D.R. Nelson, C.L. Clyde, H.D. Smith, and P.J. HaRdin. 1996. Elk and domestic sheep interactions in a north-central Utah aspen ecosystem. Research Paper INT-RP-491, USDA Forest Service, Ogden, UT.

Beck, J.L., AND J.M. PEeK. 2005a. Diet composition, forage selection, and potential for forage competition among elk, deer, and livestock on aspen-sagebrush summer range. Rangeland Ecology and Management 58:135-147.

2005b. Great Basin summer range forage quality: do plant nutrients meet elk requirements? Western North American Naturalist 65:516-527.

Beck, J.L., J.M. Peek, and E.K. Strand. 2006. Estimates of elk summer range nutritional carrying capacity constrained by probabilities of habitat selection. Journal of Wildlife Management 70:283-294.

Boyce, M.S., J.S. MaO, E.H. Merrill, D. Fortin, M.G. Turner, J. Fryxell, and P. Turchin. 2003. Scale and heterogeneity in habitat selection by elk in Yellowstone National Park. Ecoscience 10:421-431.

Boyce, M.S., P.R. Vernier, S.E. Nielsen, and F.K.A. SCHMiEgELOW. 2002. Evaluating resource selection functions. Ecological Modelling 157:281-300.

Burnham, K.P., And D.R. Anderson. 2002. Model selection and multimodel inference: a practical information-theoretic approach. 2nd edition. Springer-Verlag, New York, NY.

Carpenter, J., C. Aldridge, And M.S. Boyce. 2010. Sagegrouse habitat selection during winter in Alberta. Journal of Wildlife Management 74:1806-1814.

Cohen, J. 1960. A coefficient of agreement for nominal scales. Educational and Psychological Measurement 20:37-46.

ConRad, P.W., and W.T. McDonough. 1972. Growth and reproduction of red elderberry on subalpine rangeland in Utah. Northwest Science 46:140-148.

DeByle, N.V. 1985. Wildlife. Pages 135-152 in N.V. DeByle and R.P. Winokur, editors, Aspen: ecology and management in the western United States. General Technical Report RM-119, USDA Forest Service, Fort Collins, CO.

DoherTy, K.E. 2008. Sage-grouse and energy development: integrating science with conservation planning 
to reduce impacts. Doctoral dissertation, University of Montana, Missoula, MT.

Doherty, K.E., D.E. Naugle, and B.L. Walker. 2010 Greater Sage-Grouse nesting habitat: the importance of managing at multiple scales. Journal of Wildlife Management 74:1544-1553.

Edge, W.D., and C.L. Marcum. 1991. Topography ameliorates the effects of roads and human disturbance on elk. Pages 132-137 in Proceedings of a symposium on elk vulnerability. Montana State University, Bozeman, MT.

Edge, W.D., C.L. Marcum, and S.L. Olson-Edge. 1987. Summer habitat selection by elk in western Montana: a multivariate approach. Journal of Wildlife Management 51:844-851.

Edge, W.D., S.L. Olson-Edge, and L.L. Irwin. 1990. Planning for wildlife in national forests: elk and mule deer habitats as an example. Wildlife Society Bulletin 18:87-98.

Grover, K.E., And M.J. Thompson. 1986. Factors influencing spring feeding site selection by elk in the Elkhorn Mountains, Montana. Journal of Wildlife Management 50:466-470.

Horne, J.S., and E.O. Garton. 2006. Likelihood crossvalidation versus least squares cross-validation for choosing the smoothing parameter in kernel homerange analysis. Journal of Wildlife Management 70: 641-648.

. 2009. Animal Space Use 1.3. Available from: http:// www.cnr.uidaho.edu/population_ecology/animal_spa ce_use

Irwin, L.L., AND J.M. PeEk. 1983. Elk habitat use relative to forest succession in Idaho. Journal of Wildlife Management 47:664-672.

Johnson, C.J., S.E. Nielsen, E.H. Merrill, T.L. MCDonalD, AND M.S. Boyce. 2006. Resource selection functions based on use-availability data: theoretical motivation and evaluation methods. Journal of Wildlife Management 70:347-357.

Johnson, D.H. 1980. The comparison of usage and availability measurements for evaluating resource preference. Ecology 61:65-71.

KufELD, R.C. 1973. Foods eaten by the Rocky Mountain elk. Journal of Range Management 26:106-113.

LEBAn, F.A. 1999. Resource Selection for Windows: user's guide. University of Idaho, Moscow, ID.

Leptich, D.J., D.G. Beck, and D.E. Beaver. 1994. Aircraft-based Loran-C and GPS accuracy for wildlife research on inland study sites. Wildlife Society Bulletin 22:561-565.

LYON, L.J. 1983. Road density models describing habitat effectiveness for elk. Journal of Forestry 81:592-595.

Manly, B.F., L.L. McDonald, D.L. Thomas, T.L. McDONALD, AND W.P. ERICKSON. 2002. Resource selection by animals: statistical design and analysis for field studies. Chapman and Hall, London.

MaO, J.S., M.S. Boyce, D.M. Smith, F.J. Singer, D.J. Vales, J.M. Vore, and E.H. MERRILL. 2005. Habitat selection by elk before and after wolf reintroduction in Yellowstone National Park. Journal of Wildlife Management 69:1691-1707.

Marcum, C.L. 1975. Habitat selection and use during summer and fall months by a western Montana elk herd. Pages 91-96 in Proceedings of the Elk-LoggingRoads Symposium, University of Idaho, Moscow, ID.

McCorquodale, S.M. 2003. Sex-specific movements and habitat use by elk in the Cascade Range of
Washington. Journal of Wildlife Management 67: 729-741.

McCorquodale, S.M., K.J. Raedeke, and R.D. Taber. 1986. Elk habitat use patterns in the shrub-steppe of Washington. Journal of Wildlife Management 50: 664-669.

Millspaugh, J.J., G.C. Brundige, R.A. Gitzen, and K.J. RAEDEKE. 2000. Elk and hunter space-use sharing in South Dakota. Journal of Wildlife Management 64:994-1003.

Mower, K.J., AND H.D. Smith. 1989. Diet similarity between elk and deer in Utah. Great Basin Naturalist 49:552-555.

Muegglen, W.F. 1988. Aspen community types of the Intermountain Region. General Technical Report INT250, USDA Forest Service, Ogden, UT.

[NRCS] Natural Resources Conservation Service. 2011. Utah SNOTEL sites [online]. Available from: http:// www.wcc.nrcs.usda.gov/snotel/Utah/utah.html

Rowland, M.M., G.C. White, and E.M. Karlen. 1984. Use of pellet-group plots to measure trends in deer and elk populations. Wildlife Society Bulletin 12: $147-155$.

Rowland, M.M., M.J. Wisdom, B.K. Johnson, and J.G. KIE. 2000. Elk distribution and modeling in relation to roads. Journal of Wildlife Management 64: $672-684$.

Sappington, J.M., K.M. Longshore, and D.B. ThompSON. 2007. Quantifying landscape ruggedness for animal habitat analysis: a case study using bighorn sheep in the Mojave Desert. Journal of Wildlife Management 71:1419-1426.

SAS Institute, InC. 2009. SAS/STAT user's guide. Release 9.2. SAS Institute, Inc., Cary, NC.

Sawyer, H., AND M.J. Kauffman. 2011. Stopover ecology of a migratory ungulate. Journal of Animal Ecology 80:1078-1087.

Sawyer, H., R.M. Nielson, F.G. Lindzey, L. Keith, J.H. Powell, and A.A. Abraham. 2007. Habitat selection of Rocky Mountain elk in a nonforested environment. Journal of Wildlife Management 71: 868-874.

Scheaffer, R.L., W. Mendenhall III, and R.L. Ott. 1996. Elementary survey sampling. 5th edition. Duxbury Press, MA.

Schooley, R.L. 1994. Annual variation in habitat selection: patterns concealed by pooled data. Journal of Wildlife Management 58:367-374.

Skovlin, J.M., P. ZaGer, And B.K. Johnson. 2002. Elk habitat selection and evaluation. Pages 531-555 in D.E. Toweill and J.W. Thomas, editors, North American elk: ecology and management. Smithsonian Institution Press, Washington, DC.

Stewart, K.M., R.T. Bowyer, J.G. Kie, N.J. Cimon, And B.K. Johnson. 2002. Temporospatial distribution of elk, mule deer, and cattle: resource partitioning and competitive displacement. Journal of Mammalogy $83: 229-244$

Sweeney, J.M., AND H.W. Steinhoff. 1976. Elk movements and calving as related to snow cover. Pages 415-436 in H.W. Steinhoff and J.D. Ives, editors, Ecological impacts of snowpack augmentation in the San Juan Mountains, Colorado. Colorado State University, Fort Collins, CO.

Thomas, J.W., H. Black, R.J. Scherzinger, and R.J. Pedersen. 1979. Deer and elk. Pages 104-127 in J.W. Thomas, editor, Wildlife habitats in managed 
forests: the Blue Mountains of Oregon and Washington. USDA Forest Service, Agriculture Handbook No. 553.

Thomas, D.L., AND E.J. TaYlor. 2006. Study designs and tests for comparing resource use and availability II. Journal of Wildlife Management 70:324-336.

[USGS] United States Geological Survey. 1999. Thirtymeter national elevation data set. U.S. Geological Survey EROS data center, Sioux Falls, SD.

United States Soll Conservation Service. 1993. Utah cooperative snow survey data of federal-state-private cooperative snow surveys: water year 1993. Soil Conservation Service, Salt Lake City, UT.

Unsworth, J.W., L. Kuck, E.O. Garton, and B.R. ButTERFIELD. 1998. Elk habitat selection on the Clearwater National Forest, Idaho. Journal of Wildlife Management 62:1255-1263.
Webb, S.L., M.R. Dzialak, S.M. Harju, L.D. HadyenWing, AND J.B. Winstead. 2011. Effects of human activity on space use and movement patterns of female elk. Wildlife Society Bulletin 35:261-269.

Wisdom, M.J., A.A. Ager, H.K. Preisler, N.J. Cimon, AND B.K. JoHNSON. 2004. Effects of off-road recreation on mule deer and elk. Transactions of the 69th North American Wildlife and Natural Resources Conference 69:531-550.

Witmer, G.W., and D.S. DeCalesta. 1983. Habitat use by female Roosevelt elk in the Oregon Coast Range. Journal of Wildlife Management 47:933-939.

1985. Effect of forest roads on habitat use by Roosevelt elk. Northwest Science 59:122-125.

Received 14 September 2012 Accepted 29 July 2013

Appendixes 1-3 on pages 455-456. 
APPENDIX 1. Habitat characteristics of elk-used and available locations for each season in north central Utah, USA, 1993-1997. Numbers in parentheses for each seasonal designation represent the area $\left(\mathrm{km}^{2}\right)$ of circular analysis regions. $P$ values were obtained from independent 2-sample $t$ tests for all variables except aspect, where $P$ values were obtained from a Fisher's exact test. Degrees of freedom were 1148 for spring, 1238 for summer, 1143 for fall, and 1166 for winter.

\begin{tabular}{|c|c|c|c|c|c|c|}
\hline \multirow[b]{2}{*}{ Habitat characteristic } & \multicolumn{2}{|c|}{ Elk-used } & \multicolumn{2}{|c|}{ Available } & \multirow[b]{2}{*}{$t$} & \multirow[b]{2}{*}{$P$} \\
\hline & Mean & $\mathrm{SE}$ & Mean & SE & & \\
\hline \multicolumn{7}{|l|}{ Spring $\left(0.554 \mathrm{~km}^{2}\right)$} \\
\hline Minor roads $(\mathrm{km})$ & 0.6 & 0.1 & 0.7 & 0.02 & 0.51 & 0.612 \\
\hline Major roads (km) & 4.5 & 0.3 & 4.3 & 0.1 & 0.59 & 0.553 \\
\hline Water $(\mathrm{km})$ & 1.1 & 0.1 & 1.3 & 0.03 & 1.72 & 0.086 \\
\hline Aspen $(\%)$ & 25.0 & 1.9 & 17.1 & 0.6 & 4.63 & $<0.001$ \\
\hline Conifer $(\%)$ & 16.3 & 1.1 & 17.4 & 0.6 & 0.72 & 0.471 \\
\hline Mountain brush (\%) & 15.9 & 1.2 & 12.9 & 0.5 & 2.20 & 0.028 \\
\hline Sagebrush-meadow $(\%)$ & 42.8 & 2.5 & 52.3 & 1.1 & 3.14 & 0.002 \\
\hline Slope $(\%)$ & 20.2 & 0.8 & 20.4 & 0.3 & 0.15 & 0.881 \\
\hline Elevation (m) & 2471 & 19 & 2352 & 8 & 5.25 & $<0.001$ \\
\hline $\mathrm{VRM}^{\mathrm{a}}$ & 5.8 & 0.03 & 5.9 & 0.2 & 0.10 & 0.919 \\
\hline Aspect-warm ${ }^{b}$ & 54.7 & & 49.2 & & & \\
\hline Aspect-coolc & 45.3 & & 50.8 & & & $0.221^{\mathrm{d}}$ \\
\hline \multicolumn{7}{|l|}{ Summer $\left(0.126 \mathrm{~km}^{2}\right)$} \\
\hline Minor roads (km) & 0.5 & 0.03 & 0.6 & 0.02 & 3.04 & 0.002 \\
\hline Major roads (km) & 4.1 & 0.2 & 3.9 & 0.1 & 0.77 & 0.440 \\
\hline Water $(\mathrm{km})$ & 1.0 & 0.04 & 1.0 & 0.02 & 0.20 & 0.840 \\
\hline Aspen $(\%)$ & 34.7 & 1.6 & 22.5 & 0.7 & 7.51 & $<0.001$ \\
\hline Conifer $(\%)$ & 23.1 & 1.4 & 21.4 & 0.7 & 1.08 & 0.281 \\
\hline Mountain brush (\%) & 25.1 & 1.4 & 18.3 & 0.6 & 4.56 & $<0.001$ \\
\hline Sagebrush-meadow (\%) & 17.0 & 1.6 & 35.2 & 1.1 & 7.58 & $<.001$ \\
\hline Slope $(\%)$ & 18.7 & 0.6 & 19.2 & 0.4 & 0.53 & 0.594 \\
\hline Elevation (m) & 2610 & 9 & 2482 & 7 & 8.62 & $<0.001$ \\
\hline $\mathrm{VRM}^{\mathrm{a}}$ & 4.8 & 0.3 & 5.2 & 0.2 & 1.24 & 0.215 \\
\hline Aspect-warmb & 40.0 & & 49.6 & & & \\
\hline Aspect-coolc & 60.0 & & 50.4 & & & $0.008^{\mathrm{d}}$ \\
\hline \multicolumn{7}{|l|}{ Fall $\left(0.528 \mathrm{~km}^{2}\right)$} \\
\hline Minor roads $(\mathrm{km})$ & 0.9 & 0.1 & 0.7 & 0.02 & 2.86 & 0.004 \\
\hline Major roads $(\mathrm{km})$ & 5.4 & 0.3 & 4.5 & 0.1 & 2.67 & 0.008 \\
\hline Water $(\mathrm{km})$ & 1.4 & 0.1 & 1.3 & 0.03 & 1.37 & 0.172 \\
\hline Aspen $(\%)$ & 22.2 & 1.7 & 16.5 & 0.6 & 3.19 & 0.001 \\
\hline Conifer $(\%)$ & 20.8 & 1.4 & 17.5 & 0.6 & 2.02 & 0.044 \\
\hline Mountain brush (\%) & 16.8 & 1.4 & 12.2 & 0.5 & 3.32 & $<0.001$ \\
\hline Sagebrush-meadow (\%) & 40.2 & 2.5 & 53.6 & 1.1 & 4.38 & $<0.001$ \\
\hline Slope $(\%)$ & 25.0 & 0.9 & 21.6 & 0.4 & 3.38 & $<0.001$ \\
\hline Elevation (m) & 2477 & 20 & 2357 & 8 & 5.27 & $<0.001$ \\
\hline $\mathrm{VRM}^{\mathrm{a}}$ & 8.2 & 0.5 & 6.2 & 0.2 & 4.49 & $<0.001$ \\
\hline Aspect-warmb & 44.1 & & 49.2 & & & \\
\hline Aspect-coolc & 55.9 & & 50.8 & & & $0.286^{\mathrm{d}}$ \\
\hline \multicolumn{7}{|l|}{ Winter $(0.166$ km²) } \\
\hline Minor roads (km) & 0.9 & 0.1 & 0.6 & 0.02 & 4.45 & $<0.001$ \\
\hline Major roads (km) & 6.5 & 0.3 & 4.9 & 0.1 & 4.81 & $<0.001$ \\
\hline Water $(\mathrm{m})$ & 1.6 & 0.1 & 1.4 & 0.03 & 2.03 & 0.042 \\
\hline Aspen $(\%)$ & 10.7 & 1.4 & 12.9 & 0.7 & 1.28 & 0.202 \\
\hline Conifer $(\%)$ & 11.3 & 1.2 & 12.5 & 0.6 & 0.78 & 0.433 \\
\hline Mountain brush (\%) & 6.6 & 1.0 & 8.4 & 0.5 & 1.44 & 0.152 \\
\hline Sagebrush-meadow (\%) & 71.3 & 2.4 & 66.0 & 1.2 & 1.76 & 0.079 \\
\hline Slope $(\%)$ & 26.8 & 1.1 & 18.9 & 0.4 & 6.82 & $<0.001$ \\
\hline Elevation (m) & 2348 & 21 & 2269 & 9 & 3.42 & $<0.001$ \\
\hline VRMa & 8.4 & 0.5 & 5.6 & 0.2 & 5.53 & $<0.001$ \\
\hline Aspect-warmb & 51.8 & & 48.4 & & & \\
\hline Aspect-coolc & 48.2 & & 51.6 & & & $0.453^{\mathrm{d}}$ \\
\hline
\end{tabular}

aUnitless
bPercent circular buffers containing majority warm $\left(136-314^{\circ}\right)$ aspect

'Percent circular buffers containing majority cool $\left(135-315^{\circ}\right)$ aspect

dFrom Fisher's exact test 
Appendix 2. Top and competitive $\left(w_{i} \geq 10 \%\right.$ of top model $\left.w_{i}\right)$ models best explaining seasonal habitat selection by female elk in north central Utah, USA, 1993-1997. Null and global models are also reported for comparison.

\begin{tabular}{|c|c|c|c|c|c|}
\hline Season & Model & $\mathrm{K}^{\mathrm{a}}$ & $\mathrm{AIC}_{c}$ & $w_{i}$ & $\operatorname{Rank}^{\mathrm{b}}$ \\
\hline \multirow[t]{3}{*}{ Spring } & Aspen + Elevation & 3 & 0.00 & 0.66 & 1 \\
\hline & Aspen + Mountain brush + Elevation $[$ Global $]$ & 4 & 1.35 & 0.34 & 2 \\
\hline & Null & 1 & 39.65 & 0.00 & 8 \\
\hline \multirow[t]{6}{*}{ Summer } & Aspect + Aspen + Mountain brush + Elevation & 5 & 0.00 & 0.41 & 1 \\
\hline & $\begin{array}{l}\text { Minor roads + Aspect }+ \text { Aspen }+ \text { Mountain brush } \\
+ \text { Elevation }\end{array}$ & 6 & 1.11 & 0.23 & 2 \\
\hline & $\begin{array}{l}\text { Aspect }+ \text { Aspen }+ \text { Mountain brush }+ \text { Sagebrush- } \\
\text { meadow }+ \text { Elevation }\end{array}$ & 6 & 1.95 & 0.15 & 3 \\
\hline & $\begin{array}{l}\text { Minor roads + Aspect + Aspen + Mountain brush } \\
\quad+\text { Sagebrush-meadow }+ \text { Elevation [Global }]\end{array}$ & 7 & 3.10 & 0.09 & 4 \\
\hline & Aspen + Mountain brush + Elevation & 4 & 3.94 & 0.06 & 5 \\
\hline & Null & 1 & 131.23 & 0.00 & 64 \\
\hline \multirow[t]{3}{*}{ Fall } & Mountain brush + Slope + Elevation & 4 & 0.00 & 0.59 & 1 \\
\hline & Aspen + Mountain brush + Slope + Elevation [Global $]$ & 5 & 0.84 & 0.38 & 2 \\
\hline & Null & 1 & 46.63 & 0.00 & 16 \\
\hline \multirow[t]{3}{*}{ Winter } & $\begin{array}{l}\text { Minor roads }+ \text { Sagebrush-meadow + Slope } \\
\quad+\text { Elevation [Global] }\end{array}$ & 5 & 0.00 & 0.89 & 1 \\
\hline & Sagebrush-meadow + Slope + Elevation & 4 & 4.35 & 0.10 & 2 \\
\hline & Null & 1 & 70.37 & 0.00 & 16 \\
\hline
\end{tabular}

aNumber of parameters $(\mathrm{K})$

bithin seasonal model ranking based on $\mathrm{AIC}_{c}$

APPENDIX 3. Parameter estimates, variable importance, and odds ratios for habitat variables that were included in top models depicting seasonal habitat selection by female elk in spring, summer, fall, and winter in north central Utah, USA, 1993-1997.

\begin{tabular}{|c|c|c|c|c|c|c|c|c|}
\hline \multirow[b]{2}{*}{ Parameter } & \multirow[b]{2}{*}{ Estimate } & \multicolumn{2}{|c|}{$95 \%$ CI } & \multirow[b]{2}{*}{$P^{\mathrm{c}}$} & \multirow{2}{*}{$\begin{array}{l}\text { Relative } \\
\text { importanced }\end{array}$} & \multirow{2}{*}{$\begin{array}{l}\text { Odds } \\
\text { ratio }\end{array}$} & \multicolumn{2}{|c|}{$95 \% \mathrm{CI}$} \\
\hline & & Lower & Upper & & & & Lower & Upper \\
\hline \multicolumn{9}{|l|}{ Springa } \\
\hline Intercept & -6.553 & -8.377 & -4.729 & $<0.001$ & & & & \\
\hline Elevation (m) & 0.002 & 0.001 & 0.003 & $<0.001$ & 1.00 & 1.002 & 1.001 & 1.003 \\
\hline Aspen $(\%)$ & 0.016 & 0.008 & 0.024 & $<0.001$ & 0.99 & 1.016 & 1.008 & 1.024 \\
\hline Mountain brush $(\%)^{\mathrm{b}}$ & 0.005 & -0.007 & 0.017 & 0.411 & 0.34 & 1.005 & 0.993 & 1.017 \\
\hline \multicolumn{9}{|l|}{ Summer } \\
\hline Intercept & -9.821 & -12.185 & -7.457 & $<0.001$ & & & & \\
\hline Aspect (warm) & -0.401 & -0.726 & -0.077 & 0.017 & 0.88 & 0.669 & 0.484 & 0.926 \\
\hline Elevation $(\mathrm{m})$ & 0.003 & 0.002 & 0.004 & $<0.001$ & 1.00 & 1.003 & 1.002 & 1.004 \\
\hline Aspen $(\%)$ & 0.019 & 0.012 & 0.027 & $<0.001$ & 1.00 & 1.019 & 1.012 & 1.027 \\
\hline Mountain brush (\%) & 0.018 & 0.010 & 0.025 & $<0.001$ & 0.99 & 1.018 & 1.010 & 1.026 \\
\hline Sagebrush-meadow $(\%)^{\mathrm{b}}$ & -0.0004 & -0.009 & 0.008 & 0.937 & 0.28 & 0.999 & 0.991 & 1.008 \\
\hline Minor roads $(\mathrm{km})^{\mathrm{b}}$ & -0.158 & -0.499 & 0.183 & 0.364 & 0.36 & 0.854 & 0.607 & 1.201 \\
\hline \multicolumn{9}{|l|}{ Fall ${ }^{a}$} \\
\hline Intercept & -8.017 & -10.050 & -5.983 & $<0.001$ & & & & \\
\hline Elevation (m) & 0.002 & 0.001 & 0.003 & $<0.001$ & 1.00 & 1.002 & 1.001 & 1.003 \\
\hline Slope $(\%)$ & 0.027 & 0.011 & 0.043 & 0.001 & 0.99 & 1.028 & 1.012 & 1.044 \\
\hline Aspen $(\%)^{\mathrm{b}}$ & 0.005 & -0.004 & 0.014 & 0.271 & 0.40 & 1.005 & 0.996 & 1.014 \\
\hline Mountain brush (\%) & 0.018 & 0.007 & 0.028 & 0.002 & 0.98 & 1.018 & 1.007 & 1.028 \\
\hline \multicolumn{9}{|l|}{ Winter $^{\mathrm{a}}$} \\
\hline Intercept & -6.426 & -8.163 & -4.689 & $<0.001$ & & & & \\
\hline Elevation (m) & 0.001 & 0.001 & 0.002 & $<0.001$ & 0.99 & 1.001 & 1.001 & 1.002 \\
\hline Slope $(\%)$ & 0.040 & 0.028 & 0.053 & $<0.001$ & 1.00 & 1.041 & 1.028 & 1.054 \\
\hline Sagebrush-meadow (\%) & 0.013 & 0.008 & 0.019 & $<0.001$ & 1.00 & 1.013 & 1.008 & 1.019 \\
\hline Minor roads $(\mathrm{km})$ & 0.340 & 0.082 & 0.599 & 0.010 & 0.90 & 1.405 & 1.085 & 1.820 \\
\hline
\end{tabular}

ancludes model-averaged parameter estimates

bParameters that have no predictive power because the $95 \%$ confidence intervals of the odds ratios include 1

${ }^{\mathrm{c} P}$ values from model containing all variables in top models

dCalculated by adding Akaike weights for all models within a season that a variable was present in 